\title{
Innovation research on foreign language teaching theory with Chinese characteristics based on Whitehead's process philosophy
}

Hui Su*

\author{
${ }^{*}$ Correspondence: \\ suhui53@126.com \\ Zhengzhou University \\ of Aeronautics, No. 2, Middle \\ University Road, Zhengzhou \\ City, Henan Province, China
}

\begin{abstract}
Since China's reform and opening up, foreign language teaching (FLT) in China has achieved rapid development under the guidance of foreign language teaching theories both at home and abroad. However, problems such as 'time-consuming and inefficient foreign language learning' and the presence of 'dumb foreign languages' in FLT in China have not been fundamentally solved. Based on Whitehead's process philosophy, this research aims to put forward feasible solutions to the existing problems in FLT in China so that the level of FLT in China can be promoted by discussing the purpose, contents, processes and stages of FLT and the relationship between teachers and students in both FLT and FLT evaluation systems.
\end{abstract}

Keywords: Alfred North Whitehead, Process philosophy, Foreign language teaching, Foreign language teaching theories with Chinese characteristics

\section{Introduction}

Studies on FLT theories in China have experienced three important phases, namely, the introduction, local transformation and development, and innovation phases of FLT theories(Wen, 2019). Many researchers have emerged in the field and produced a large number of research outcomes regarding FLT theories through their research aims, including not only ideas, evaluations, methods and the reform of FLT, but also foreign language learners' learning strategies and motivation, etc. Especially since the reform and opening up, an increasing number of foreign language researchers have become progressively more interested in research focused on FLT theories combined with FLT practices in China (Chen, 2015). A series of theoretical achievements have been obtained (Wen, 2019), such as Zhengdong Zhang's three-dimensional approach to FLT (Zhang \& Du, 1999), Sizhong Zhang's 16-Chinese-character FLT method (Zhang, 2006), Tianren Bao's four-in-one model of FLT (Chen, 2015), Chuming Wang's length-in-writing approach to foreign language learning (Wang, 2005), Cheng Ma's three-in-one model of English teaching (Ma \& Lan, 2011), Qiufang Wen's production-oriented approach to FLT (Wen, 2015) and Jianzhong Zhang's ten-Chinese-character model or five-factor model of English teaching (Zhang, 2016).

(c) The Author(s), 2021. Open Access This article is licensed under a Creative Commons Attribution 4.0 International License, which permits use, sharing, adaptation, distribution and reproduction in any medium or format, as long as you give appropriate credit to the original author(s) and the source, provide a link to the Creative Commons licence, and indicate if changes were made. The images or other third party material in this article are included in the article's Creative Commons licence, unless indicated otherwise in a credit line to the material. If material is not included in the article's Creative Commons licence and your intended use is not permitted by statutory regulation or exceeds the permitted use, you will need to obtain permission directly from the copyright holder. To view a copy of this licence, visit http:// creativecommons.org/licenses/by/4.0/. 
These achievements have provided a solid theoretical basis for the practice of FLT in China and have greatly promoted its development. However, the current problems existing in FLT in China have not been fundamentally solved. Considering this issue, this research, which is based on China's national condition and foreign language teaching and learning situation, aims to put forward new theoretical insights into FLT with Chinese characteristics from the perspective of Whitehead's process philosophy.

\section{Problem statement}

A theory can be defined as a set of statements or principles that have been devised to explain a group of facts or phenomena, especially one that has been repeatedly tested or is widely accepted and can be used to make predictions about natural phenomena. Theories come from practices and can be used to guide them. FLT theories have been derived from FLT practices. There are quite a few FLT theories that can be found both at home and abroad. These theories are usually applied to offer guidance to FLT practices worldwide. However, no theory is applicable to all contexts. Due to the introduction of FLT theories from abroad, great achivements have been made in regard to foreign language education in China. However, problems such as 'time-consuming and inefficient foreign language learning' and the presence of 'dumb foreign languages' in FLT in China are still prominent (Wang, X. \& Zhang, Y., 2007:367; Wu, 2004) . "Depending on FLT theories from abroad and lacking innovation on FLT theories rooted in the special contexts in China contribute to the phenomena" (Wang \& Li, 2017: 1). Of course, "there is no denying that FLT theories from abroad are not scientific. The main reason is that they are applied is according to the peculiar contexts and characteristics of language learners in China" (Wu \& Huang, 2019:39). Different countries have their own peculiarities regarding the purposes, contexts and traditions of FLT.Thus, FLT theories should be applied according to the peculiarities in China. Although there some scholars have proposed FLT theories with Chinese characteristics, these theories are not all-around or systematic. This means that problems still exist in FLT in China. Therefore, innovation in FLT has become a necessity because the "linguistic,cultural and functional diversity associated with English today challenges some of the fundamental assumptions of ELT and requires that we revisit our pedagogical practices" (Rose et al., 2021). Therefore, consructing an all-around and systematic theoretical frame of FLT with Chinese characteristics is a feasible way to fundamentally solve the current problems.

\section{Research objectives}

This research has two main objectives. First, it seeks to investigate the prominent problems that currently exist in regard to foreign language education in China. Second, it tries to propose systematic theoretical insights into FLT that may provide effective guidance for the practice of FLT in China based on Whitehead's process philosophy.

\section{Research questions}

According to the research objectives, the research questions are posed as follows:

1. What are the main problems that exist in foreign language education in China?

2. Why is Whitehead's process philosophy important for education? 
3. What are the main principles of Whitehead's process philosophy?

4. Does Whitehead's process philosophy bring enlightenment to foreign language teaching in China?

\section{Significance of the research}

The existing research on FLT theories mainly focuses on specific points without having a comprehensive, systematic and relative point of view. As a result, the effect of FLT in China has not been satisfactory thus far. To solve this problem, the current research is conducted from a philosophical point of view based on Whitehead's process philosophy, which can clearly bring enlightenment to education. This research seeks to propose comprehensive, systematic and relative theoretical insights into FLT, which will be of great importance to the practice of FLT in China.

\section{Methodology}

The literature review methodology is applied in this present research. The review starts out from the analysis of quite a few FLT theories with Chinese characteristics and reveals their important roles in improving the practice of FLT in China. Then, works related to the current situation of FLT in China are examined. It has been found that there still exist obvious problems in FLT in China, for example, 'time-consuming and inefficient foreign language learning' and the presence of 'dumb foreign languages', etc. These problems are not conducive to the fulfillment of the purpose of FLT in China. Additionally, the previously proposed theories do not offer effective guidance for the practice of FLT in China.

Considering this lack, it is necessary to conduct research on theories of FLT from a new point of view so that feasible solutions to the existing problems can be found. With the intention of solving these problems, I have comprehensively studied Whitehead's process philosophy and related academic works and I have found that this approach can bring great enlightenment to education. Therefore, this research aims to obtain enlightenment from Whitehead's process philosophy that can be applied to FLT in China.

Finally, based on Whitehead's process philosophy, this research aims to put forward feasible solutions to the existing problems in FLT in China so that the level of FLT in China can be promoted by discussing the purpose, contents, processes and stages of FLT and the relationship between teachers and students in both FLT and FLT evaluation systems. These systematic theoretical insights into FLT will provide effective guidance for the practice of FLT in China.

\section{Literature review of FLT theories with Chinese characteristics}

Since China's reform and opening up, the Chinese researchers of foreign language teaching theories have realized that simply introducing FLT theories from abroad is an approach that has been unable to meet the real needs of the practice of FLT in China. Many researchers have combined their research on FLT theories with China's national condition and FLT teaching learning situation and has consequently proposed a series of FLT theories with Chinese characteristics (Chen, 2015). 
Zhengdong Zhang constructed his theoretical framework of FLT by integrating his views on the FLT environment in China, the nature of foreign language learning, the cultural differences between China and foreign countries, the economic development that affects the effectiveness of FLT, and the teachers who play homeostasis roles in FLT. The main arguments of this theory are the psychological views of both FLT and foreign language learning, five elements, the system and teachers' homeostasis roles.

To solve the problem of Chinese students' inability to use foreign languages fluently and accurately in real life although they had learned them for many years, Professor Chuming Wang proposed a new teaching model named the length-in-writing approach. This is one method of promoting foreign language learning in a writing-focus way. With tasks designed to stimulate students to write essays as its teaching focus, this model, which complies with the foreign language learning rules, helps students break through the limits of foreign language learning and express their true feelings in the writing; thus, their senses of achievements and confidence in foreign language learning can be greatly enhanced by gradually adjusting the length of their compositions and increasing their amount of writing (Wang, 2005). Then, students' foreign language knowledge can be transformed into their language application abilities in a much quicker way. Chuming Wang holds the view that the length-in-writing approach can help the students overcome their psychological barriers in foreign language learning; it can help them enhance their senses of achievements and self-confidence; it can consolidate their learned language knowledge and transform it into their application abilities more quickly and it can stimulate students to give full play to their potentials (Wang, 2005; Wen, 2005).

Through decades of foreign language teaching practice, Sizhong Zhang formed the 16-Chinese-character FLT method, namely, "appropriate concentration, repeated circulation, reading the original works, and individualizing the teaching approach to each student's aptitude" (Zhang, 2006). 'Appropriate concentration' refers to the centralized processing of language knowledge and skills with the emphasis that it is easy to determine teaching and learning rules in such a way that the teaching effect can be improved. 'Repeated circulation' aims to help students strengthen their memories of language knowledge through a high repetition rate of that knowledge by means of different memorial methods. Sizhong Zhang believes that 'reading original works' is an important approach to foreign language learning, which can not only cultivate students' good reading habits and consolidate their foreign language knowledge but also enrich students' foreign cultural knowledge and improve their interest in foreign language learning. 'Individualizing the teaching approach to each student's aptitude' means that a duplex teaching method is used to creatively handle the differences between students to ensure a good teaching effect, according to different teaching and learning situations and teaching materials.

Tianren Bao's four-in-one approach to FLT takes 'a step by step approach with emphasis on stages, intensive teaching and practising, and five skills (i.e., listening, speaking, reading, writing and translating) with equal importance' as the teaching principles. This approach is student-centered with teachers playing guiding roles. It also advocates the view that foreign languages should be learned with the consolidation and improvement of students' basic language knowledge and skills as its teaching focus. 
Cheng Ma's three-in-one model of FLT contains two parts. One is called the minor three-in-one model of FLT, which refers to the teaching of characters, phonemes and phonetic symbols. The minor model emphasizes the importance of phonetics teaching in helping students speak foreign languages. The other model is named the major three-in-one model of FLT, which denotes the teaching of vocabulary, grammar and reading. The major model attaches great importance to the order of FLT and holds that FLT should be conducted in accordance with the optimal order of vocabulary, grammar and reading to achieve the ideal teaching effect.

Wen (2015) proposed a brand new FLT theory, namely, the "production-oriented approach". This theory takes the 'learning-centered principle', 'learning-using integrated principle' and 'whole-person education principle' as its teaching ideas. It advocates that FLT should help students learn languages effectively, integrate language learning and use, and finally achieve the goal of improving students' comprehensive abilities to use foreign languages. Additionally, this approach emphasizes the important roles of language output and selective learning in foreign language learning.

Jianzhong Zhang proposed the ten-Chinese-character model or five-factor model of FLT (Zhang, 2016). This model refers to the learning process in which the students, with a strong will and relaxing emotions, actively and effectively participate in communication activities in specific language cognitive contexts by using foreign languages, with the language structures and grammatical rules being practised and generalized and undertaking appropriate study strategies for self-monitoring and selfadjusting. This model is made up of five factors, i.e., language cognitive contexts, students' emotions, language structures, communication activities and study strategies.

To probe into effective foreign language teaching, Shiyu Wu has put forward the 'reading for discussion model' for foreign language teaching with meaning communication as its core by combining the peculiar foreign language teaching context and characteristics of Chinese learners with the interaction hypothesis, input hypothesis, comprehensible output hypothesis as well as socialcultural theory (Wu \& Huang, 2019). This model is "one of content and language integrated learning with its focus on training students' communication skills in reading, writing and speaking” (Wu \& Huang, 2019:44).

To address the "incompleteness" that has long existed in foreign language education in China, including the "incompleteness" of the purpose, program and practice of foreign language education, Baocheng Han proposed a holistic approach towards foreign language education that is composed of the concepts of "whole language teaching content", "whole language learning" and "whole language teaching" (Han, 2018). According to the holistic approach based on the philosophy of education, foreign language education should aim at whole person development. In addition, the theory holds that "the selection and arrangement of foreign language teaching contents should be based on students' interests, cognitive characteristics and language learning rules" (Han \& Liang, 2019:583). The approach stresses the "the importance of rich, comprehensible and complete input and output" (Han, 2018:52). It also emphasizes the use of dynamic interactive activities that help to promote both comprehension and production (Han, 2018). This approach is actually a holistic model of FLT with meaning construction and whole person development as its goals. 
These theoretical achievements of FLT with Chinese characteristics have made FLT in China more localized, thereby meeting the real needs of the practice of FLT in China. With their guidance, FLT in China has been greatly promoted. However, the existing problems in FLT indicate that these theories haven not offered effective guidance for the practice of FLT in China(Chen, 2015). In fact, they are not systematic for foreign language education. Hence, new research on FLT theories with Chinese characteristics is urgently needed.

\section{Present situation and existing problems related to FLT in China}

Since China's reform and opening up, FLT in China has obtained brilliant achievements. Not only have FLT courses and syllabuses been constantly improved, but FLT materials have also made great progress in regard to both quality and quantity. However, there still exist many problems in FLT in China. These problems can be generally summarized as follows.

\section{Prominent problems such as time-consuming and inefficient foreign language learning and dumb foreign languages}

Many Chinese students have learned foreign languages for more than ten years, yet they are still unable to express their ideas in those foreign languages either idiomatically or fluently. In fact, their comprehensive abilities in listening to, speaking, reading, writing and translating foreign languages have not been effectively improved.

\section{Insufficient studies on FLT theories}

FLT has its own rules. The practice of FLT should be carried out based on a full understanding of FLT rules, objects and methods. Regrettably, there is still a lack of serious, comprehensive and profound research on FLT theories. This lack directly hinders the improvement of FLT in China.

First, professional researchers who focus on FLT theories are insufficient in China. At present, authoritative FLT research institutions are not numerous enough in China. In addition, the majority of the researchers are not full-time researchers. Most of them do their research on FLT theories just out of interest without proper research plans. Furthermore, research on FLT theories cannot obtain adequate support from middle schools or colleges. This is not conductive to the achievements FLT theories.

In addition, most teachers have low literacy in regard to FLT theories, and they also do not attach much importance to FLT theories (Dai \& Zhang, 2001; Shu, 2005). Some even hold that FLT does not need any guidance from the FLT theories. Thus, they do not apply any FLT theories to their teaching. In addition, others view that FLT theories are too abstract and idealistic to guide the practice of FLT in China (Shu, 2005).

\section{Less qualified teachers}

The qualification of the teachers is a key factor in FLT. Currently, the number of foreign language learners in China is increasing rapidly, while the teachers are in short supply. To meet the real needs of language learners, teachers of different levels of qualification are employed. Qualified foreign language teachers are not numerous enough ( $\mathrm{Li}, 2003)$. The overall quality of foreign language teachers is not high (Dai, 2001; Shu, 2004). Some 
teachers have low levels of foreign language literacy and competence in regard to language teaching. Such teachers can hardly provide learners with accurate and effective help. Other teachers, due to their heavy teaching load, find it difficult to spare time to study the rules of FLT, which leads to low levels of theoretical literacy in regard to FLT (Shu, 2005). As a result, the prospect of improving the quality of FLT becomes slim.

\section{Backward teaching theory and unitary teaching method}

At present, teaching approaches and methods cannot meet the needs of FLT practice in China. FLT is still knowledge-centered. Language teachers attach great importance to imparting language knowledge to learners rather than valuing their abilities in language application (Huang \& Xia, 2013; Xia, 2002). Moreover, the most prevalent teaching method is the grammar translation method. Although some other teaching methods are also used, for example, listening and speaking methods, communicative methods, and task-based teaching methods, most teachers believe that the grammar translation method is the most effective one due to the pressure of exams (Dai \& Zhang, 2001; Liu \& Dai, 2003; Shu, 2004).

\section{Exam-oriented teaching}

Currently, the effectiveness of FLT at all levels in China is mainly evaluated through exams. In fact, the current approach to FLT is exam-oriented (Chen, 2013; Sheng, 2008; Shu, 2004). The ultimate purpose of this approach seems to help the learners pass exams. Therefore, language learners are always confronted with all kinds of exams, including midterm and final exams, CET-4, CET-6, IELTS, TOEFL, etc. (Wang, 2011, 2013; Zhou, 2011). They learn foreign languages simply by spending huge amounts of time doing exercises so that they can pass these exams. This is undoubtedly not useful for learners' true mastery of foreign languages because of its inconsistency with the rules of FLT.

\section{Whitehead's process philosophy}

\section{The principles of Whitehead's process philosophy}

Alfred North Whitehead (1861-1947) was an outstanding logician, mathematician, philosopher and educator in the $20^{\text {th }}$-century. He was the founder of process philosophy, which has exerted a great influence on research on modern philosophy and pedagogics. Additionally, known as the philosophy of organisms, process philosophy contains several principles, namely, the principles of process, prehension, relativity, subjectivity and relativity, which have brought enlightenment to foreign language education in China.

Process is the core category of Whitehead's process Philosophy. According to the principle of process, "the actual world is a process and that the process is the becoming of actual entities, how an actual entity becomes constitutes what that actual entity is and thus its 'being' is constituted by its 'becoming"' (Whitehead, Griffin \& Sherburne, 1978:22 \& 23; Wei, 2016:96). Process is the way of an actual entity's being, without which no actual entity can exist, let alone develop itself.

Prehension, which is also a concrete fact of relatedness, refers to the process of an actual entity's appropriation of a particular element. The principle of prehension holds that each actual entity is not an independent being but rather a relevant entity that 
originates from its prehension. There are two species of prehensions, namely, positive prehensions, which are termed 'feelings', and 'negative prehensions', which are said to 'eliminate from feeling.' All actual entities are positively prehended.

Whitehead's principle of relativity holds that relativity is the common nature of every actual entity. No actual entity exists by itself; rather, it is relevant to other actual entities. "The whole physical world is held together by a universal relationship, which forms it into an extensive continuum" (Yang \& McDaniel, 2018: 271).

According to the principle of subjectivity, "the whole universe consists of the elements disclosed in the analysis of various subjects' experiences and process is the becoming of experience" (Yang \& McDaniel, 2018: 284). Whitehead points out that only actual entities' experience of activities could be regarded as actual and that "apart from the experiences of subjects there is nothing, nothing, nothing, bare nothingness" (Whitehead, Griffin \& Sherburne, 1978: 167).

The principle of creativity holds that creativity is the intrinsic nature of all actual entities in the universe, i.e., actual entities' intrinsic power of self-generation. Creativity, being the form of every becoming, is the ultimate cause of all actual entities' becoming and the power of all novel entities. No actual entity can exist without creativity. Thus, the whole universe is a creative process, i.e., "a creative progress towards novelty" (Yang \& McDaniel, 2018: 312).

\section{Whitehead's philosophy of education}

In London, Whitehead became involved in many practical aspects of tertiary education. By linking his ideas on education with his process philosophy, Whitehead developed his own philosophy of education, which is embodied in his representative book The Aims of Education and Other Essays.

\section{The aims of education}

Whitehead's philosophy of education holds that "the whole aim of education is the production of active wisdom" (Li, F. \& Wen, H., 2012:51) and that "education is not a process of packing articles in a trunk" (Whitehead, 1967:33). Whitehead points out that education should aim at imparting to students the most intellectually nourishing knowledge and skills, just as living organisms absorb the nutrients of food, so that ultimately their wisdom can be developed. Students, in Whitehead's opinion, are active living organisms with creativity. Therefore, it is the purpose of education to stimulate and guide each student's self-development. The true value of education lies in enlightening learners' wisdom instead of merely imparting knowledge. Thus, Whitehead opposes uniform exams. He argues that when learners become the machines and slaves of examinations, they will become "bookworms" who lack intelligence, imagination, and creativity. As a result, their wisdom can hardly be enlightened.

\section{The process view of education}

Whitehead believes that the actual world is a constantly changing and dynamic process and thus, the educational process should be emphasized. Whitehead holds that "life is essentially periodic" (Whitehead, 1967:17), and he conceives of the learner's educational process of self-development as an organic and cyclic process in which each cycle 
consists of three stages; first is the stage of romance, then comes the stage of precision, and finally, there is the stage of generalization. Additionally, he holds that "education should consist in a continual repetition of the threefold cycles of the romance, precision and generalization stages" and that the students will enjoy some fruition if the teacher stimulates in exact proportion to his or her success in satisfying their rhythmic cravings (Whitehead, 1967:19). According to Whitehead, the romance, precision and generalization stages are present throughout education. However, the point is that there is an alternation of dominance, which constitutes the three cycles.

\section{Whitehead's view on knowledge}

Whitehead advocates active education. He holds that "education is the acquisition of the art of the utilization of knowledge" (Whitehead, 1967:4) and "for successful education there must be a certain freshness in the knowledge dealt with, which must either be new in itself or be invested with some novelty of application to the new world of new times since it doesn't keep any better than fish" (Whitehead, 1967:98). Therefore, Whitehead emphasizes that knowledge should be kept alive and prevented from becoming inert, which is the central problem of all education.

\section{Enlightenment of Whitehead's process philosophy to education}

As an outstanding philosopher and educator in the $20^{\text {th }}$-century, Alfred North Whitehead's principles of process philosophy are of great significance in regard to developing an education theory. According to Whitehead, the aim of education is the production of active wisdom. He opposes the exam-oriented teaching model that stresses too much the accumulation of knowledge; rather, he advocates organic education and one model that attaches great importance to creativity and relativity and aims at developing students' wisdom.

Whitehead holds that "the actual world is a process and that the process is the becoming of actual entitie, how an actual entity becomes constitutes what that actual entity is and thus its 'being' is constituted by its 'becoming"' (Whitehead, Griffin \& Sherburne, 1978:22 \& 23; Wei, 2016:96). Therefore, the process attribute of education should be emphasized (Guo, 2005).

Whitehead argues that life is the only source of education by pointing that "there is only one subject-matter for education, and that is life in all its manifestations" (Whitehead, 1967:6 \& 7). Thus, the content for education should be related to students' real lives.

Whitehead embraces a dynamic view of the universe. He thinks that the actual entities that constitute the whole universe are changing all the time. Thus, everthing should be viewed dynamically.

Process philosophy also holds that the ultimate actual entities of the world are interrelated organisms. An organism is a continuum in the continuous processes of becoming, changing and perishing. Organisms come into their beings by prehending each other. By existing in interdependent events, they integrate into a broader, and interactive community. Teachers and students, i.e., the actual entities of education constitute their community, thereby prehending and influencing each other. 
All the principles of Whitehead's process philosophy have brought great enlightenment to the educational aim, process, contents and evaluation as well as teacher and student relationships. With this enlightenment, a more holistic and systematic educational theory can be constructed.

\section{Implications for theoretical insights with chinese characteristics towards FLT} FLT should focus on cultivating students' wisdom in using foreign language knowledge

According to Whitehead, the aim of education is the production of active wisdom rather than the accumulation of knowledge, similar to packing articles in a trunk. Thus, the ultimate aim of foreign language education lies in cultivating students' wisdom in using foreign language knowledge, i.e., cultivating their comprehensive abilities in foreign language application instead of flooding them with huge amounts of knowledge.

However, FLT in China still emphasizes language knowledge input without attaching due importance to students' ability to use this knowledge in real contexts under the great influence of the exam-oriented teaching model. This leads to the phenomenon that students learn foreign languages by obtaining language knowledge from teachers. In fact, in the practice of FLT, the teaching of language knowledge occupies most of the class hours, while the training of students' practical ability in using foreign languages is not given due attention. This can surely account for Chinese students' time-consuming and inefficient foreign language learning and the presence of dumb foreign languages. Considering this, FLT in China should eliminate the exam-oriented model, value foreign language input and output, and shift its focus from the cultivation of students' abilities for exams to that of their foreign language application wisdom to stimulate and guide students' self-development.

\section{FLT should value the processes and stages of language teaching and learning}

The processes and stages of language teaching and learning should be given more attention. Whitehead holds that "the actual world is a process and that the process is the becoming of actual entitie, how an actual entity becomes constitutes what that actual entity is and thus its 'being' is constituted by its 'becoming"' (Whitehead, Griffin \& Sherburne, 1978:22 \& 23; Wei, 2016:96). A process is the way of an actual entity's being, without which no actual entity can exist, let alone develop itself. 'Teaching' and 'learning' in FLT are two actual entities. They can only exist and be developed in processes. Therefore, foreign language teachers should pay more attention to the changing and developing processes of the interrelationship and interaction between the relevant elements in foreign language teaching and learning. In addition, attention should be given to the key events and students' 'personalized participation' and 'dialogic participation' in their learning process so that favourable conditions can be created to promote the realization of the objectives of FLT.

Foreign language education should follow the threefold cycles of romance, precision and generalization. Whitehead points out that education has a rhythm, and he divides the rhythm of education into three stages; first is the stage of romance, then comes the stage of precision, and finally, there is the stage of generalization (Whitehead, 1967:1720). Additionally, he holds that "education should consist in a continual repetition of the threefold cycles of the romance, precision and generalization stages" (Whitehead, 
1967 :19). Foreign language education, of course, should follow this rhythm. In the romance stage, proper guidance should be offered to arouse students' initiative towards foreign language learning, stimulate their interest in learning foreign languages, and let them freely and romantically experience the fun of foreign language learning. Consequently, students' lasting passion for foreign language learning can be generated. In the precision stage, attention should be given to grammar learning and the accuracy of language knowledge. In the generalization stage, great importance should be attached to the improvement of students' comprehensive abilities in using foreign languages. Favourable conditions should be created to help students use their learned language knowledge in real situations. Following this approach, students can they truly improve their foreign language application abilities. Consequently, the cyclic cycles of the three stages should be reflected in FLT so that the ultimate purpose of foreign language education can be realized.

\section{The 'teachers and students community' and 'cooperative learning model' should be constructed in FLT}

The relationship between teachers and students is a special interpersonal relationship, "in which human educational activities are carried out and completed" (Wei, 2017:16). Without teachers and students, educational activities would be like water without a source. In FLT practice, it is very important to clarify the relationship between teachers and students. However, as they are influenced by 'substantial thinking', the current teaching models, such as the 'teacher-oriented teaching model' and 'student-oriented teaching model', clearly reveal the binary opposition in the teacher-student relationship. In certain teaching activities, teachers and students are always staying in a closed learning environment yet isolated from each other, which seriously restricts their growth. This is not conducive to the realization of the purpose of FLT.

Thus, a 'teachers and students community' should be constructed. Process philosophy holds that the ultimate actual entities of the world are interrelated organisms. An organism is a continuum in the continuous processes of becoming, changing and perishing. Organisms come into their beings by prehending each other. By existing in interdependent events, they integrate into a broader and interactive community. Teachers and students are the basic actual entities in FLT. They are interdependent and prehending each other (Wei, 2019), thereby constituting a community. Therefore, as the active participants of equal status in FLT, teachers and students should solve the problems that occur in the processes of teaching and learning by approaching them on an equal footing ( $\mathrm{Li}$, B. \& Wang, H., 2011).

FLT is the process of mutual prehending between teachers and students, i.e., learning from each other. It does not simply contain teachers' teaching and students' learning. In the community of FLT, teachers and students are cooperative and mutually promote their growth. Teachers are not the authorities who impart knowledge, and students are not merely passive receivers of knowledge. Hence, students' one-way learning mode has been unable to meet their practical needs of FLT. Considering this, a new cooperative learning model should be constructed. First, teachers should stimulate students' initiative and interest in foreign language learning and guide them to experience the process of discovering foreign language knowledge so as to promote their desire for further 
foreign language learning. Second, teachers should pay more attention to students' real needs for foreign language learning, actively cooperate with them to explore various schemes of teaching and learning and help them solve the problems that they encounter in the process of foreign language learning. Such a cooperative learning model is indeed conducive to the improvement of both foreign language teaching and learning, which will ultimately produce the teaching effect of ' $1+1>2$ '.

\section{The content of FLT should be life-oriented}

The content of FLT ought to be related to students' real lives. Whitehead advocates active education. He emphasizes that knowledge should be kept alive and prevented from becoming inert since "it doesn't keep any better than fish" (Whitehead, 1967:98). $\mathrm{He}$ also argues that life is the only source of education by pointing out that "there is only one subject-matter for education, and that is life in all its manifestations" (Whitehead, 1967:6 \& 7). Therefore, the content of FLT should be closely related to students' lives. Only the real events in their lives can truly draw their interest, which "is the sine qua non for attention and apprehension" (Whitehead, 1967:31). Unfortunately, at present, the content of FLT in China mainly comes from the outdated teaching materials in coursebooks that do not truly reveal Chinese students' real life, especially their culture (Du, 2015; Xu, 2019). This kind of material can hardly arouse students' interest. As a result, such material cannot be quite helpful to students' foreign language learning. Interest is the best teacher. Thus, FLT content ought to arouse students' interest (Shu, 2010). That is, "the selection and arrangement of foreign language teaching content should be based on students' interests" (Han \& Liang, 2019: 583). Teaching content should be closely related to students' lives and reflect their culture (Tang, 2015). Only this content can truly help students prehend what they learn with great interest so that their creative transformation of foreign languages can be boosted and thus their comprehensive foreign language literacy can thereby be improved.

\section{A pluralistic and dynamic evaluation system should be constructed in FLT}

Teaching and its evaluation accompany each other. There are no teaching activities without any evaluation. Teaching evaluation involves measuring and judging the value of teaching activities through certain evaluation standards based on the teaching objectives. For a long time, teaching evaluations in China have been regarded as isolated and static under the great influence of substantive thinking (Li, 2013). This approach, separated from the processes of teaching and learning, does not pay attention to specific teaching situations or the interrelationship between the teaching elements. At present, the evaluation of FLT in China is mechanical and static due to its unitary subject and one-sided content. This method cannot comprehensively reveal the real processes of foreign language teaching or learning, which, to a large extent, hinders the improvement of the quality of FLT in China.

The construction of a pluralistic and dynamic evaluation system of FLT should be completed. This method can involve the following aspects. First, more subjects should participate in the evaluation process. The evaluation of teaching and learning cannot be confined to teachers' unilateral behaviour. Multiple subjects should take part in the evaluation process. Process philosophy holds that both subjects and objects are generated 
through the processes of the interaction between actual entities. Hence, the subject and object of the evaluation process are generated through the process of language teaching and learning, which may shift each other under certain conditions. Either teachers or students may become the subject or object of the evaluation process (Guo, 2005). Therefore, both teachers and students ought to participate in the evaluation process as the subjects. In addition, other subjects can be involved. These subjects may be experts in foreign languages or staff in charge of teaching and learning. The presence of multiple subjects in the evaluation process will make the process more objective and comprehensive. Second, the evaluation methods should be diversified. The summative evaluation based on exams mainly focuses on the outcome of students' foreign language learning but neglects their learning process. This approach cannot comprehensively reveal how students learn foreign languages. Students' learning process of foreign languages should become the focus of the evaluation. Evaluation methods can take various forms, such as classroom activities and self-study files. Third, the content of the evaluation should be more inclusive. Currently, the evaluation content mainly includes the evaluation of students' mastery of foreign language knowledge, but it excludes other important factors, such as teachers' and students' personalities, emotions, psychologies and attitudes. The evaluation content should involve not only students' mastery of language knowledge but also their learning attitudes, learning strategies, interests, emotions, classroom performance and abilities in regard to using foreign languages. Furthermore, the evaluation should be a dynamic process. According to process philosophy, the whole world is constituted by organisms that exist in the processes with mobile and rheological properties. As an organism, such an evaluation should exist throughout the whole process of teaching and learning with its objective, content, method, and subject being dynamically changed.

\section{Discussion}

From the research, it can be found that there still exist obvious problems regarding FLT in China, such as time-consuming and inefficient foreign language learning and the presence of dumb foreign languages, insufficient research on FLT theories, less qualified teachers, backward teaching theory, unitary teaching methods, and exam-oriented teaching, all of which have led to the unsatisfactory effect of FLT. This finding reveals that the current FLT theories have not offered effective guidance for the practice of FLT in China. Considering this, an innovation in FLT theories is needed.

The research indicates that Whitehead's process philosophy is of great importance to education. Indeed, its main principles, that is, the principles of process, prehension, relativity, subjectivity, relativity, and philosophy of education have brought clear enlightenment to FLT in China. The aim of foreign language education should focus on students' development in all respects, especially that in their wisdom, emotions and morality (Wen, 2015). The content of FLT should be closely related to students' real lives. Whitehead argues that "there is only one subject-matter for education, and that is life in all its manifestations" (Whitehead, 1967:6 \& 7). Only interesting materials in real life can arouse students' interest. When their interest is piqued, students can indulge themselves in their language learning (Shu, 2019). Therefore, "the selection and arrangement of foreign language teaching contents should be based on students' interests" (Han \& 
Liang, 2019). In addition, elements of FLT are always in a dynamically changing process. Thus, not only FLT evaluation but also foreign language teaching and learning processes should be viewed dynamically. Moreover, the research has cast new light on the relationship between teachers and students. The current binary opposite teacher-student relationship no longer suits FLT. Teachers and students are the basic actual entities in FLT, as they prehend and influence each other. Consequently, they ought to cooperate with each other, which can contribute to their mutual growth. Hence, a cooperative learning model should be constructed that is conducive to the improvement of both foreign language teaching and learning.

In summary, the holistic and systematic theoretical insights into FLT that have been proposed based on the enlightenment from Whitehead's process philosophy will most likely be meaningful to the practice of FLT in China.

\title{
Conclusion
}

In summary, research on the theory of FLT with Chinese characteristics is necessary. Theories can be applied to guide practice. Hence, theories of FLT will play important roles in guiding its practice. However, the contexts and characteristics of FLT vary in different countries (Wang \& Liu, 2021; Wu \& Huang, 2019). Research on FLT theories with Chinese characteristics can obtain achievements only by exploring the unique teaching and learning situations in China. Based on Whitehead's process philosophy, this paper has discussed the purpose, content, processes and stages of FLT and the relationship between teachers and students in both FLT and FLT evaluation systems. Several theoretical views have been put forward. These views will contribute to the solutions to the existing problems related to and the improvement of FLT in China.

\author{
Abbreviation \\ FLT: Foreign language teaching. \\ Acknowledgements \\ Acknowledgments are not applicable for this manuscript. \\ Authors' contributions \\ The author completed the whole manuscript on his own. \\ Funding \\ The author received no financial support for this research, authorship and publication of this article. \\ Availability of data and materials \\ Data sharing is not applicable to this article as no datasets were generated or analyzed during the current study.
}

\section{Declarations}

Competing interests

The authors declare that they have competing interests.

Received: 18 May 2021 Accepted: 30 October 2021

Published online: 15 November 2021

\section{References}

Chen, G. (2013). An empirical study of college English intercultural teaching: problems and countermeasures-based on a case study of Heilong Jiang University of Science and Technology. Shanghai International Studies University.

Chen, Y. (2015). A study on English teaching and learning approaches in China from indigenous aspect. Hunan Normal University. https://doi.org/10.7666/d.Y2801584 
Dai, W. (2001). Reflections on the "time-consuming and inefficient" phenomenon in foreign language teaching and its countermeasures. Journal of Foreign Languages and Their Teaching, 7, 1-32.

Dai, W., \& Zhang, X. (2001). A probe into the theoretical system of english teaching with Chinese characteristics: Reflections and suggestions. Journal of Foreign Languages Research, 2, 1-4. https://doi.org/10.3969/j.issn.1005-7242.2001 02.001

$\mathrm{Du}, \mathrm{H}$. (2015). A research on the current situation of Chinese cultural infiltration in college English teaching. Guangxi Normal University. https://doi.org/10.7666/d.Y2846752

Guo, Y. (2005). On the process attribute and value of education. Journal of the Educational Research, 9, 3-8.

Han, B. (2018). The holistic approach toward foreign language teaching and its core concepts. Journal of Foreign Language Education, 39(2), 52-56. https://doi.org/10.16362/j.cnki.cn61-1023/h.2018.02.011

Han, B., \& Liang, H. (2019). A road map for the holistic approach toward foreign language teaching. Journal of Foreign Language Teaching and Research, 51(4), 583-595.

Huang, G., \& Xia, J. (2013). A study of college English classroom crisis and its countermeasures. Journal of Foreign Language Learning Theory and Practice, 3, 17-20.

$\mathrm{Li}, \mathrm{B}$. \& Wang, H. (2011). Whitehead's philosophy of education and its enlightenment to college education in China. Journal of the Higher Education Exploration, 1, 29-33.

Li, F., \&Wen, H. (2012). Researches on process-based education in China. Fujian Education Press.

Li, G. (2003). Learning and teaching of the English language: A personal account. Journal of Foreign Languages, 1, 50-55. https://doi.org/10.3969/j.issn.1004-5139.2003.01.008

Li, L. (2013). A research on the reform of teaching evaluation based on process philosophy. Journal of the Education and Vocation, 32, 117-118. https://doi.org/10.13615/j.cnki.1004-3985.2013.32.011

Liu, R., \& Dai, M. (2003). A research on the current situation of the reform and development strategies of foreign language teaching in China. Foreign Language Teaching and Research Press.

Ma, C., \& Lan, S. (2011). Cheng Ma: The three-in-one model of English teaching. Capital Normal University Press.

Rose, H., McKinley, J., \& Galloway, N. (2021). Global Englishes and language teaching: A review of pedagogical research. Language Teaching, 54(2), 157-189. https://doi.org/10.1017/S0261444820000518

Sheng, X. (2008). Cultural reflection on college English teaching. Journal of Foreign Languages in China, 5(5), 10-14. https://doi.org/10.13564/j.cnki.issn.1672-9382.2008.05.010

Shu, D. (2004). Foreign language teaching in China: Problems and suggested solutions. Shanghai Foreign Language Education Press.

Shu, D. (2005). China needs foreign language teaching theories with Chinese characteristics. Journal of the Foreign Language World, 6, 2-7.

Shu, D. (2010). What should be taught in college English classrooms and how to teach? An Essay Written at the End of the First National College English Teaching Competition Held by Shanghai Foreign Language Education Press, 6, 26-32.

Shu, D. (2019). Foreign language teaching should seek to integrate the traditional teaching methods and the communicative teaching method-Mr. Guanyi Li's View and suggestions for foreign language teaching. Journal of Foreign Language World, 2, 16-23.

Tang, J. (2015). Sociocultural factors' influence on the system of foreign language teaching evaluation. Journal of Social Scientist, 5, 133-136. https://doi.org/10.3969/j.issn.1002-3240.2015.05.028

Wang, S. (2011). Several reflections on college English teaching. Journal of Foreign Language Teaching Theory and Practice, 2(1), 1-5.

Wang, C. (2005). The length-in-writing approach to foreign language learning. Journal of the Foreign Languages in China, 2(1), 45-49.

Wang, S. (2013). Sticking to the scientific approach to the reform of college English teaching. Journal of the Foreign Language World, 6, 1-6.

Wang, W., \& Liu, X. (2021). The issues of foreign language education: Research and practice in China. Journal of Foreign Languages and Their Teaching, 1, 1-12. https://doi.org/10.13458/j.cnki.flatt.004738

Wang, X., \& Zhang, Y. (2007). Quests for foreign language education-essays of Weidong Dai. Shanghai Foreign Language Education Press.

Wei, S. (2016). Curriculum construction based on process philosophy: Concept, value and implementation. Journal of Nanjing Normal University(Social Science Edition), (03), 96-104. https://doi.org/10.3969/j.issn.1001-4608.2016.03.012

Wei, S. (2017). A research on the construction of 'teachers and students community': A reflection on the relationship between teachers and students based on process philosophy. Journal of the Higher Education of Sciences, 3, 15-22. https://doi.org/10.3969/j.issn.1000-4076.2017.03.003

Wei, S. (2019). Contemporary classroom reform: A reflection on process philosophy. Journal of the Modern Education Management, 12, 63-68. https://doi.org/10.16697/j.cnki.xdjygl.2019.12.010

Wen, Q. (2015). Developing a theoretical system of the production-oriented approach in language teaching. Journal of the Foreign Language Teaching and Research, 47(4), 547-558.

Wen, Q. (2005). An analysis of the length-in-writing approach to foreign language learning. Journal of the Modern Foreign Languages, 28(3), 308-311. https://doi.org/10.3969/j.issn.1003-6105.2005.03.011

Wen, Q. (2019). Foreign language teaching theories in China in the past 70 years. Journal of the Foreign Languages in China, 16(5), 14-22. https://doi.org/10.13564/j.cnki.issn.1672-9382.2019.05.003

Whitehead, A. N. (1978). Process and reality: An essay in cosmology (corrected edition edited by David Ray Griffin and Donald W.Sherburne). Macmillan Publishing Co. The Free Press, 22-23, 167)

Whitehead, A. N. (1967). The aims of education and other essays (pp. 4-98). The Free Press.

Wu, S., \& Huang, S. (2019). What is 'effective' foreign language teaching? Theoretical reflections on foreign language teaching based on the teaching context and the characteristics of learners in China. Journal of Contemporary Foreign Lanquages Studies, 03, 37-47. https://doi.org/10.3969/j.issn.1674-8921.2019.03.003

Wu, X. (2004). An analysis of the causes of "time-consuming and inefficient" college English teaching. Henan Education College Journal, 23(3), 112-113. https://doi.org/10.3969/j.issn.1006-2920.2004.03.025 
Xia, J. (2002). A survey report on college English Teachers'foreign language education concepts, knowledge, ability, present situation of scientific research and further study. Journal of Foreign Language World, 5, 35-41.

Xu, X. (2019). A survey of the phenomenon of "Chinese Culture Aphasia" in college English teaching. Unpublished master's dissertation, Shanxi University of Finance \& Economics.

Yang, F., \& McDaniel, J. (2018). On Whitehead's process philosophy (pp. 271-312). China Renmin University Press.

Zhang, W. (2016c). Applying production-oriented approach to college English classrooms: A teaching experiment. Journal of the Foreign Languages and Their Teaching, 2, 106-114.

Zhang, J. (2016). Ten-Chinese-character model of English teaching. Fujian Education Press.

Zhang, S. (2006). Sizhong Zhang and his 16-Chinese-character foreign language teaching method. Beijing Normal University Press.

Zhang, Z., \& Du, P. (1999). The three-dimensional principles and model of foreign language teaching. Science Press.

Zhou, Y. (2011). A study on the relationship between examination-oriented education and the employment of language learning strategies. Unpublished master's dissertation, Southwestern University of Finance and Economics.

\section{Publisher's Note}

Springer Nature remains neutral with regard to jurisdictional claims in published maps and institutional affiliations.

\section{Submit your manuscript to a SpringerOpen ${ }^{\circ}$ journal and benefit from:}

- Convenient online submission

- Rigorous peer review

- Open access: articles freely available online

- High visibility within the field

- Retaining the copyright to your article

Submit your next manuscript at $\gg$ springeropen.com 